\title{
The potential of combining UAV and remote sensing in supporting precision mapping of irrigation systems for paddy land in urban agricultural areas: study case in the Hoa Vang district, Danang city, Central Vietnam
}

\author{
Nghiên cứu tiềm năng kết hợp UAV với viễn thám trong việc hỗ trợ độ chính xác của bản đồ hệ \\ thống nguồn nước tưới cho đất trồng lúa ở vùng nông nghiệp đô thị: Trường hợp nghiên cứu \\ ở huyện Hòa Vang, thành phố Đà Nã̃ng, Miền Trung Việt Nam
}

TRAN, Phuong Thi*; TRUONG, Phuong Do Minh; HO, Hoang Viet; NGUYEN, Hai Thi; NGUYEN, Ngoc Bich

University of Agriculture and Forestry, Hue University, 102 Phung Hung Street; Hue City, Vietnam

\begin{abstract}
This research was carried out to test the potential of combining unmanned aerial vehicle (UAV) and remote sensing (RS) to support precision mapping of irrigation systems for paddy land. The study area is an urban/agricultural area of Central Vietnam. The Sentinel-2A imagery acquired on 30 June 2018 was interpreted according an object-based classification method aiming to map paddy land and irrigation systems for the Hoa Vang district; the total accuracy was $91.33 \%$ with a Kappa coefficient of 0.87 . However, with the spatial resolution from the Sentinel-2A images (20 meters $\times 20$ meters) it was difficult to classify paddy land and water from other objects within small and scattered parcel areas. This research was designed on five experimental flying zones, collecting 2,085 images by the UAV. With the very high spatial resolution data of the UAV, it was possible to clearly identify the boundaries of paddy land parcels, water sources such as rivers and lakes, and other objects such as canals and concrete irrigation systems. This classification derived from the orthogonal images from the five experimental zones using an object-based classification method, correcting the interpretation results of the Sentinel 2A images. Outcomes indicate that, the combination of UAV and RS can be applied to support precision mapping of irrigation systems for paddy land in urban agricultural areas.
\end{abstract}

Nghiên cứu này được thực hiện nhằm thử nghiệm khả năng kết hợp giữa UAV với viễn thám trong hỗ trợ độ chính xác của bản đồ hệ thống nước tưới cho đất trồng lúa ở vùng nông nghiệp đô thị tại Miền trung Việt Nam. Ảnh viễn thám Sentinel- $2 \mathrm{~A}$ thu nhận vào 30/6/2018 đã được giải đoán bằng phương pháp định hướng đối hướng để thành lập bản đồ hệ thống nguồn nước tưới cho huyện Hòa Vang vào năm 2018, với kết quả độ chính xác tổng số là 91,33\% và hệ số kappa là 0,87. Mặc dù với kết quả giải đoán có độ chính xác cao nhưng với độ phân giải không gian của ảnh Sentinel-2A là 20m x 20m rất khó để phân loại được các vùng đất lúa có diện tích nhỏ và phân bố phân tán. Nghiên cứu này đã thiết kế 5 khu vực bay thử nghiệm với 2.085 ảnh để thu thập dữ liệu từ UAV. Có thể thấy rằng dữ liệu ảnh từ UAV với độ phân giải siêu cao có thể nhận diện và phân biệt được một cách rõ ràng không chỉ ranh giới của các thửa đất lúa, hệ thống nguồn nước như sông hồ, mà còn cả những đối tượng kênh mương thủy lợi nhỏ. Kết quả giải đoán các ảnh bay chụp bằng UAV sử dụng dụng phương pháp định hướng đối tượng, nghiên cứu này đã hiệu chỉnh được kết quả giải đoán ảnh Sentinel $2 A$. Kết quả cho thấy việc kết hợp dữ liệu viễn thám với UAV là hoàn toàn có khả năng sử dụng để hỗ trợ độ chính xác thành lập bản đồ hệ thống nguồn nước cho đất trồng lúa ở vùng nông nghiệp đô thị.

Keywords: irrigation system; paddy land; precision mapping; remote sensing; UAV

\section{Introduction}

Under changing climatic conditions, irrigation plays an important role in agricultural production in order to meet the global food demand (Tilman \& Clark, 2015). Consequently, better irrigation plans are applied as an effective solution to fulfil the increasing food demand in accordance with the global population growth (Thenkabail et al., 2009). Therefore, more attention is being given to the assessment of irrigation performance to improve water management, to achieve a higher water productivity and to increase the sustainability of agricultural water; providing accurate information on irrigation areas is beneficial for a good water management. However, the extent and distribution of irrigation areas have not yet been 
determined despite the significant effects of irrigation on food security and water resources. Currently, irrigation maps are worldwide available at different spatial resolutions. Among them, irrigation maps of the Food and Agriculture Organization (FAO) of the United Nations (Ozdogan et al., 2010), the Global Map of Irrigated Areas version 5 or GMIA 5.0 (Ribeiro-Gomes et al., 2017) and the Global Rain-Fed Irrigated and Paddy Croplands (GRIPC) with spatial resolution of $500 \mathrm{~m}$, produced using Moderate resolution imaging spectre radiometer (MODIS) satellite data (Siebert et al., 2015). The low spatial resolution of these maps is an obstacle for their use in irrigation management, especially for small agricultural areas. On a regional scale, a number of attempts have been made to map irrigation areas using remote sensing data (Dheeravath et al., 2010; Gumma et al., 2011). Nowadays, free and open access Sentinel-2 data, with high re-access times, provides a powerful tool for small-scale irrigation mapping (Bazzi et al., 2019; Demarez et al., 2019; Gumma et al., 2011). The Sentinel satellites provide a special combination of high spatial and temporal resolution for dual polarized SAR data, available as free open access. Remote sensing technology has the advantage of operating well in real time, having wide coverage on arable land and at the same time, compensating for immobile sensor defects.

The development of aerospace technology makes irrigation planning possible using remote sensing imaging platforms, being drones (UAVs) and satellites popular tools (Ren et al., 2016; Ribeiro-Gomes et al., 2017). UAVs are lowcost but can provide information with a high-level accuracy at low-altitude given the little interference from clouds (Han et al., 2018). Remote sensing applications, using UAVs in agriculture, have proved to be an effective tool for gathering field information (Mengmeng Du \& Noboru Noguchi, 2017). UAVs can be used for mapping at close range, incorporating interchangeable aerial and ground image measurements for aerial mapping technology in small-scale areas (Henri Eisenbeiss, 2011). Studies have shown some practical experiences in using drones in combination with remote sensing technology to create accurate agricultural maps (Catus Aries Rokhmana, 2015). UAVs, also named Drones, can be exploited in a wide variety of applications with regard to crop management and large spatial resolution photography (Dimosthenis et al., 2019).

Thus, it can be seen that the application of remote sensing technology in mapping surface water bodies for agriculture has become popular in many parts of the world. Besides, there is still no specific study on the application of remote sensing technology in combination with drone technology to develop a zoning map for irrigation water for rice cultivation.

This study proposes an innovative approach to create a map of water for irrigation of rice cultivation areas using remote sensing images (Sentinel-2A) in combination with UAV. This study contributes in evaluating the combination of RS and UAV to support precision mapping of irrigation systems for paddy land in the Hoa Vang district, an urban agricultural area in Central Vietnam.

\section{Materials and methodologies}

\subsection{Site selection}

Hoa Vang is the only agricultural district of Danang city, located in $7 \mathrm{~km}$ from the city center. This district comprises 11 communes with a total non-urbanized area of 73,317 ha with agricultural areas comprising 64,879 ha, accounting for $88.28 \%$ of the non-urbanized land. The terrain is diverse extending over three regions, being mountainous, midland and flat land. The mountainous region is comprised by the Hoa Bac, Hoa Ninh, Hoa Phu and Hoa Lien communes with an elevation ranging from $400 \mathrm{~m}$ to $500 \mathrm{~m}$; it covers an area of $78.66 \%$ of the total natural land of the district. The midland region is characterized by a semi-mountainous terrain consisting of relatively low hills and low mountain front plains; low hills with an elevation ranging from 50 to $100 \mathrm{~m}$ alternating with narrow fields, accounting for $17.18 \%$ of the natural area of the district; The flat region presents elevations from $2 \mathrm{~m}$ to $10 \mathrm{~m}$, occupying $4.16 \%$ of total natural area. Livelihood in the Hoa Vang district is dependent on agricultural production, despite being one of the areas most affected by droughts. Droughts are distributed in all of the 11 communes during the Summer-Autumn season. Rice is one of most sensitive crops to drought in this district.

\subsection{Research methods}

\subsubsection{Data collection methods}

Sentinel imagery, acquired on June 30th 2018, was collected at 2A level, geometrically corrected with a cloud coverage of $6.3 \%$ and $20 \mathrm{~m} \times 20 \mathrm{~m}$ of spatial resolution. Data was free downloaded from Land Viewer - EOS (https://eos.com/landviewer/). The current land use map (2015 release) was obtained from the Office of Natural Resources and Environment in Hoa Vang district; from this map, district and commune boundaries were extracted to clip the remote sensing imagery. Prior to the image classification and the accuracy assessment, a field survey of paddy rice fields, cultivated in Summer-Autumn season, was conducted from June to July 2018 to obtain training and validation datasets.

\subsubsection{RS and UAV images classification using object-oriented method}

The Object-Oriented Classification method was applied to interpret Sentinel 2A image. The image was pre-processed on ArcGIS software according to the boundaries for further classification steps. To build an object-oriented classification, image fragmentation was carried out based on the selection of weights for shape, color, compactness, 
smoothness and scale of parameters. Based on the defined surface coating classification system, the parameters for image fragmentation were checked and tested several times. The results were fragmented by 3 levels corresponding to the classification of objects. The results are summarized in Table 1 . This study used the classification error matrix to determine the accuracy of image interpretation; the results are based on the total accuracy and Kappa coefficient (K). The $\mathrm{K}$ value ranges from 0 to 1; a strong agreement and a good accuracy is achieved when $\mathrm{K}>0.8$, a middle accuracy when $\mathrm{K}=0.4$ 0.8 , and a poor accuracy when $\mathrm{K}<0.4$ (Anthony J. and Joanne M., 2005).

\section{Table 1. Fragmentation level of Sentinel 2A images by classification object}

\begin{tabular}{llllll}
\multirow{2}{*}{ Fragmentation level } & \multicolumn{2}{l}{ Standard parameters } & Fragmentation & Classified object \\
& Scale & Shape & Compactness & number & Water surface and land \\
\hline Level 1 & 15 & 0.2 & 0.5 & 213.007 & Land with well-developed vegetation and Land with \\
Level 2 & 10 & 0,1 & 0.5 & 557.012 & little / no vegetation \\
Level 3 & 25 & 0.2 & 0.5 & 202.516 & Land for rice cultivation and Other agricultural land \\
\hline
\end{tabular}

\subsubsection{Combining RS and UAV data method}

The UAV data processing was initially conducted on Agisoft PhotoScan software to create orthogonal images for each flight area. Accordingly, the captured images of each area were imported to the software, converting geographic coordinates into the VN2000 coordinate system using the Projection and Transformation Tool in ArcGIS software.
After performing a geometric correction, based on ground surface points, orthogonal UAV imagery was exported (as *.tif format) to be further processed on ArcGIS software. The Supervised Classification method was used to further interpret the Sentinel 2A imagery; the classification was based on the previous interpretation of the UAV imagery in order to correct the classification results for the areas that not undergoing experimental flight in the district.
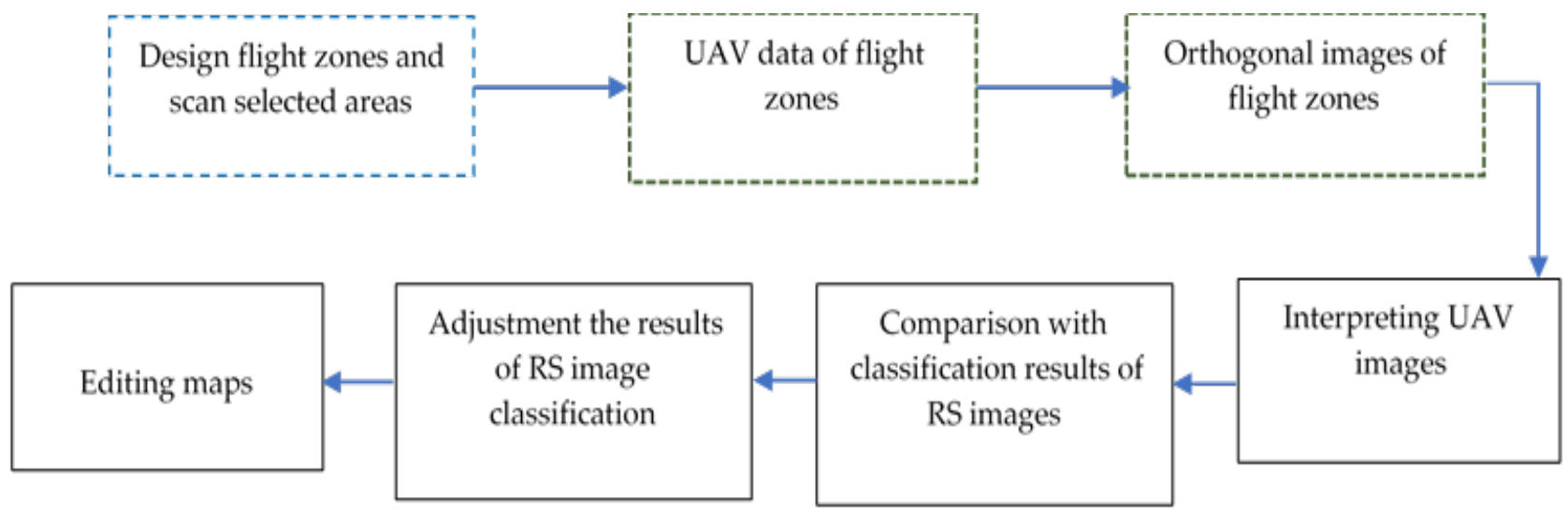

\section{Drone Deploy _----- Agisoft PhotoScan _ ArcGIS}

\section{Figure 1. Combining RS and UAV in in supporting precision mapping}

Supervised Classification was performed by the Image Classification Analysis tool included in ArcGIS. Identified pixel samples from UAV imagery were used to assign values and classify Sentinel 2A imagery in areas not covered by the UAV.

\section{Results and discussions}

\subsection{Mapping irrigation system for paddy land based on remote sensing image}

The accuracy of the classification results was the decisive factor for the analysis of right or wrong topical contents. An error matrix and the Kappa coefficient were used to check the accuracy of the classification results. To facilitate the accuracy assessment and the analysis of the two main objects, paddy rice land and water surface land, this study combined classification results of the Hoa Vang district into 3 categories: paddy rice cultivation area, surface water and other remaining land use types (including other agricultural land and areas with little or no vegetation growth).

After determining threshold values of the indicators from the satellite imagery, key levels and sets of interpretation for each classification type in the Hoa Vang district were defined as shown in figure 2 . The image classification accuracy, according to the remote sensing object-oriented method, was assessed using a grid of 300 points of ground 
truth data samples at the time of image acquisition. Evaluation of the results shows that the overall accuracy is 91.33\% with an overall Kappa coefficient of 0.87 (table 2).
According to Cohen J, (1960), this is considered as a strong agreement and a good accuracy for optical remote sensing image data which has medium resolution.

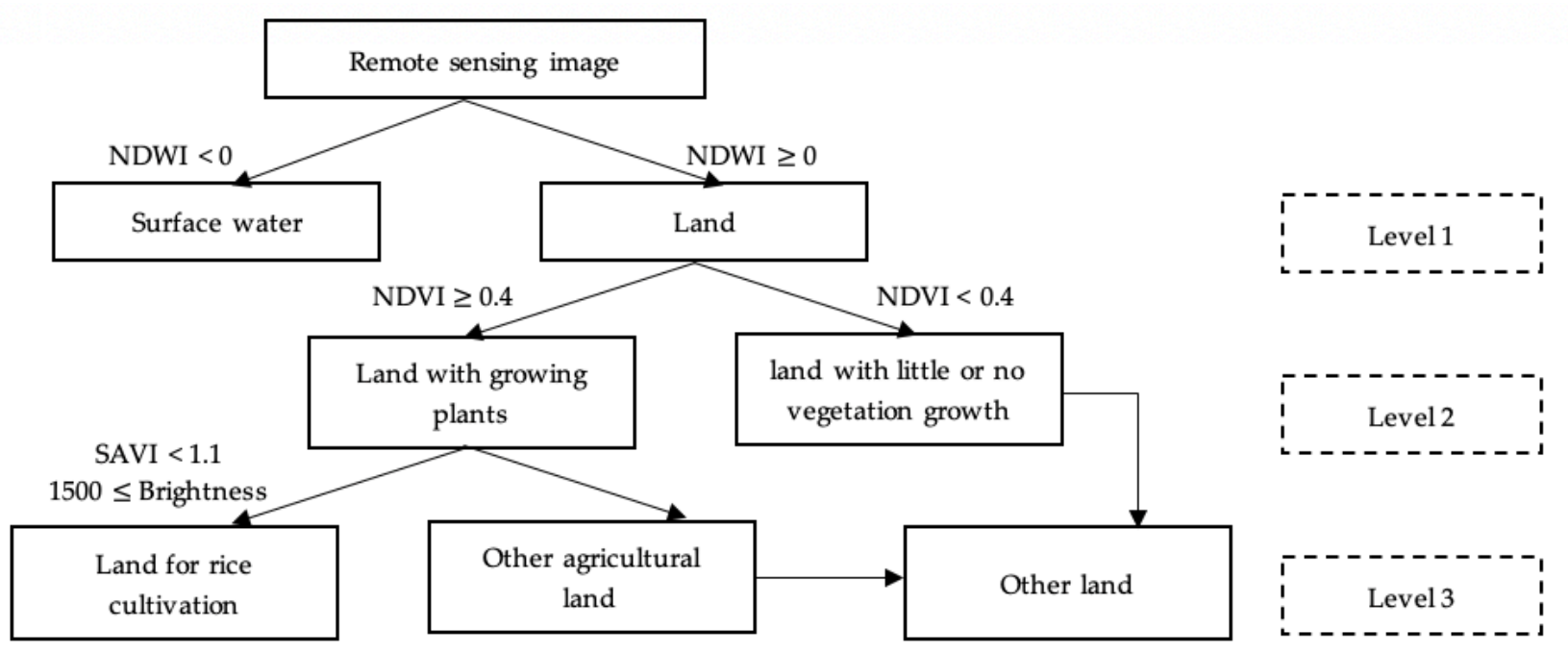

Figure 2. Hierarchy diagram and interpretation key sets of object classification of the Hoa Vang district surface coating for Sentinel 2A photos obtained on June 30, 2018

Table 2. Matrix and accuracy assessment results

\begin{tabular}{lllll} 
Classification & Water surface land & Land for rice cultivation & Other land & Total \\
\hline Water surface land & 96 & 3 & 2 & 101 \\
Land for rice cultivation & 3 & 89 & 10 & 102 \\
Other land & 1 & 7 & 89 & 97 \\
Total & 100 & 99 & 101 & 300 \\
Overall accuracy & $91.33 \%$ & & & \\
Kappa Coefficient & 0.87 & & & \\
\hline
\end{tabular}

Results of surface coating classification from eCognition software were converted to process and edit the current map of rice cultivation land and surface water sources using ArcGIS software. Surface water systems for irrigation of rice cultivation land were classified and edited by using simultaneously the current rice cultivation land, the surface water sources map, the land use map and group discussions with stakeholders.

\subsection{Comparing spatial resolution of remote sensing and UAV images}

There were five experimental flight zones designed for this research. However, due to the principle of overlapping and composite images processing of Agisoft PhotoScan software, orthogonal images, formed after the UAV data processing, had different boundaries in comparison to those from the defined flight area (Table 3). Therefore, orthogonal images were cropped according to the boundaries of each flight area to ensure the uniformity of data and to facilitate further steps (Fig. 3). After the UAV data processing, classification results from both, remote sensing and UAV, were evaluated. Table 4 shows that for the same area, the Sentinel 2A imagery, with a resolution of $20 \mathrm{~m} \times 20 \mathrm{~m}$, only identified paddy land and water sources having medium and large areas. Therefore, with this resolution is more difficult to identify paddy land or water sources if they are small and scattered distributed.

Table 3. UAV images information of the five experiment zones

\begin{tabular}{|c|c|c|c|c|c|c|}
\hline Commune name & Zones & Height (m) & Coverage $(\%)$ & Total images & Area (ha) & Flight time \\
\hline \multirow[t]{3}{*}{ Hoa Lien } & No. 1 & $\approx 100$ & 80 & 636 & $\approx 47,75$ & $38 \mathrm{~m} 23 \mathrm{~s}$ \\
\hline & No. 2 & $\approx 75$ & 80 & 667 & $\approx 36,31$ & $33 \mathrm{~m} 24 \mathrm{~s}$ \\
\hline & No. 3 & $\approx 75$ & 80 & 441 & $\approx 23,08$ & $22 \mathrm{~m} 16 \mathrm{~s}$ \\
\hline \multirow[t]{2}{*}{ Hoa Ninh } & No. 1 & $\approx 50$ & 80 & 115 & $\approx 5,72$ & $14 \mathrm{~m} 34 \mathrm{~s}$ \\
\hline & No. 2 & $\approx 50$ & 80 & 226 & $\approx 9,55$ & $22 \mathrm{~m} 17 \mathrm{~s}$ \\
\hline
\end{tabular}



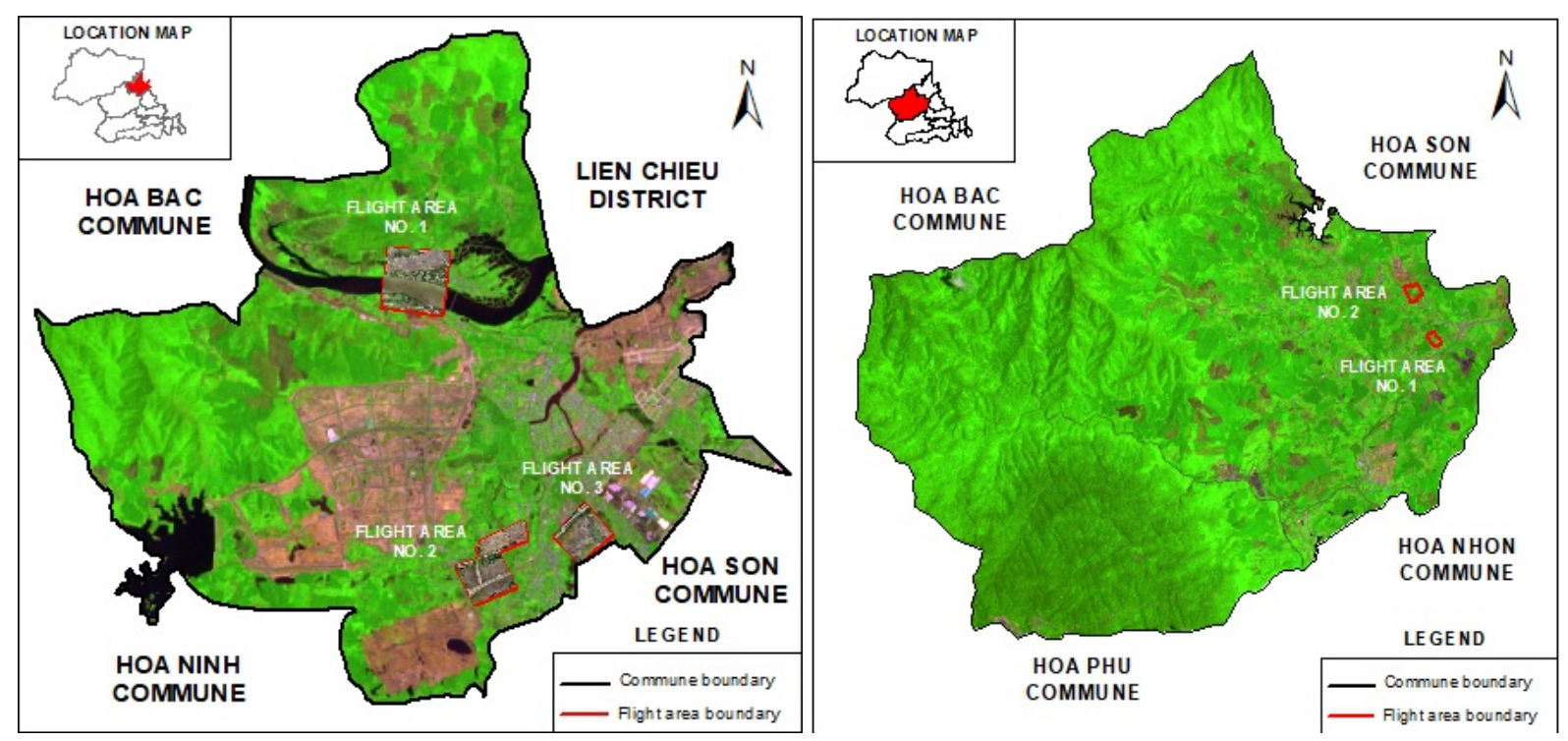

Figure 3. UAV flight zones in Hoa Lien (left) and Hoa Ninh (right) communes

Table 4. Comparing remote sensing and UAV images in the same location at five experiment flight areas

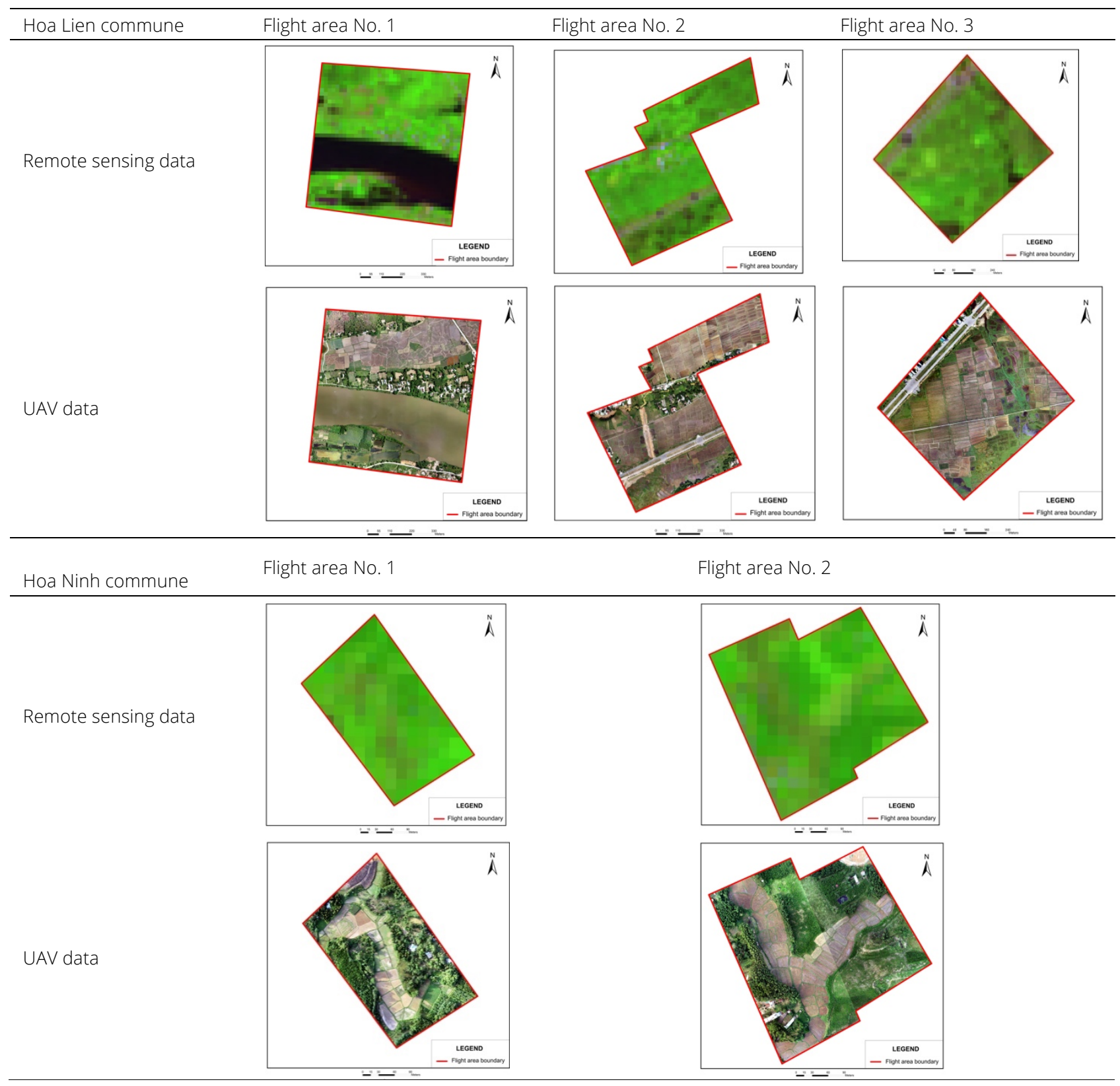


On the other hand, due to the higher resolution of UAV data, it was possible to clearly identify the paddy land and water sources, including concrete and alluvial canals (Fig. 4). Thus, combining UAV and remote sensing data is a viable process to map objects not clearly identified by the sole use of remote sensing imagery.

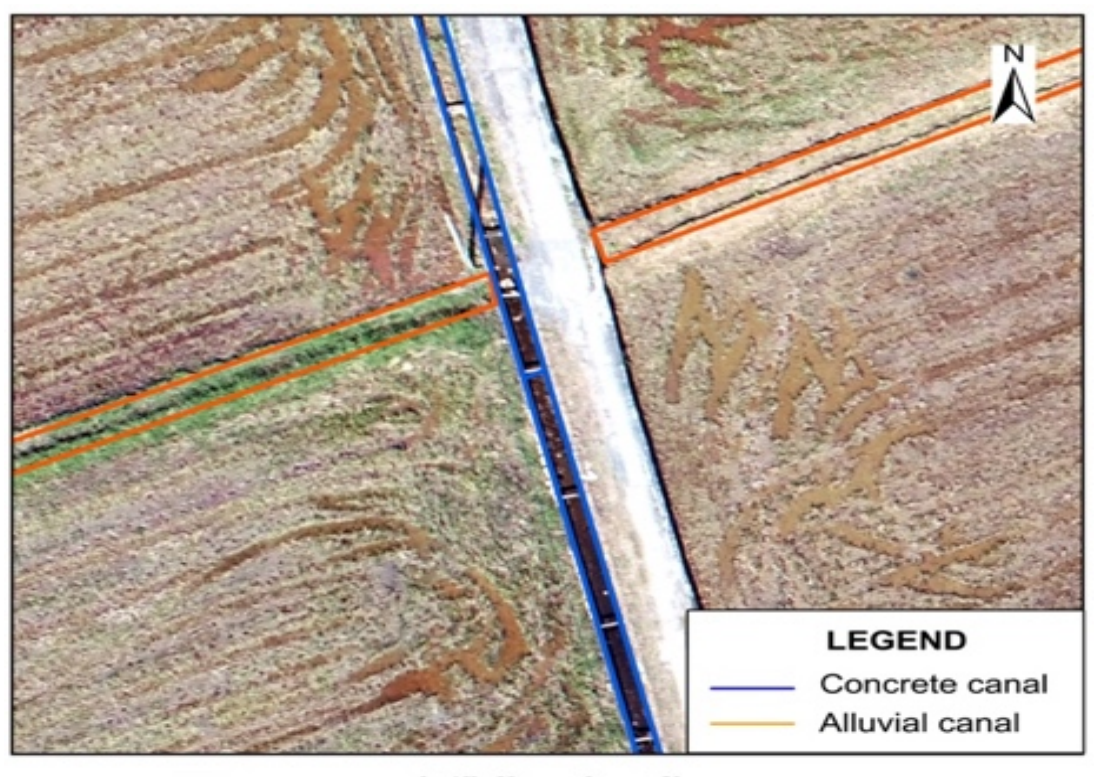

Figure 4. Identifying irrigation system by UAV images

Table 5. Comparing classification results from remote sensing data and UAV data in the same location at five experiment flight areas

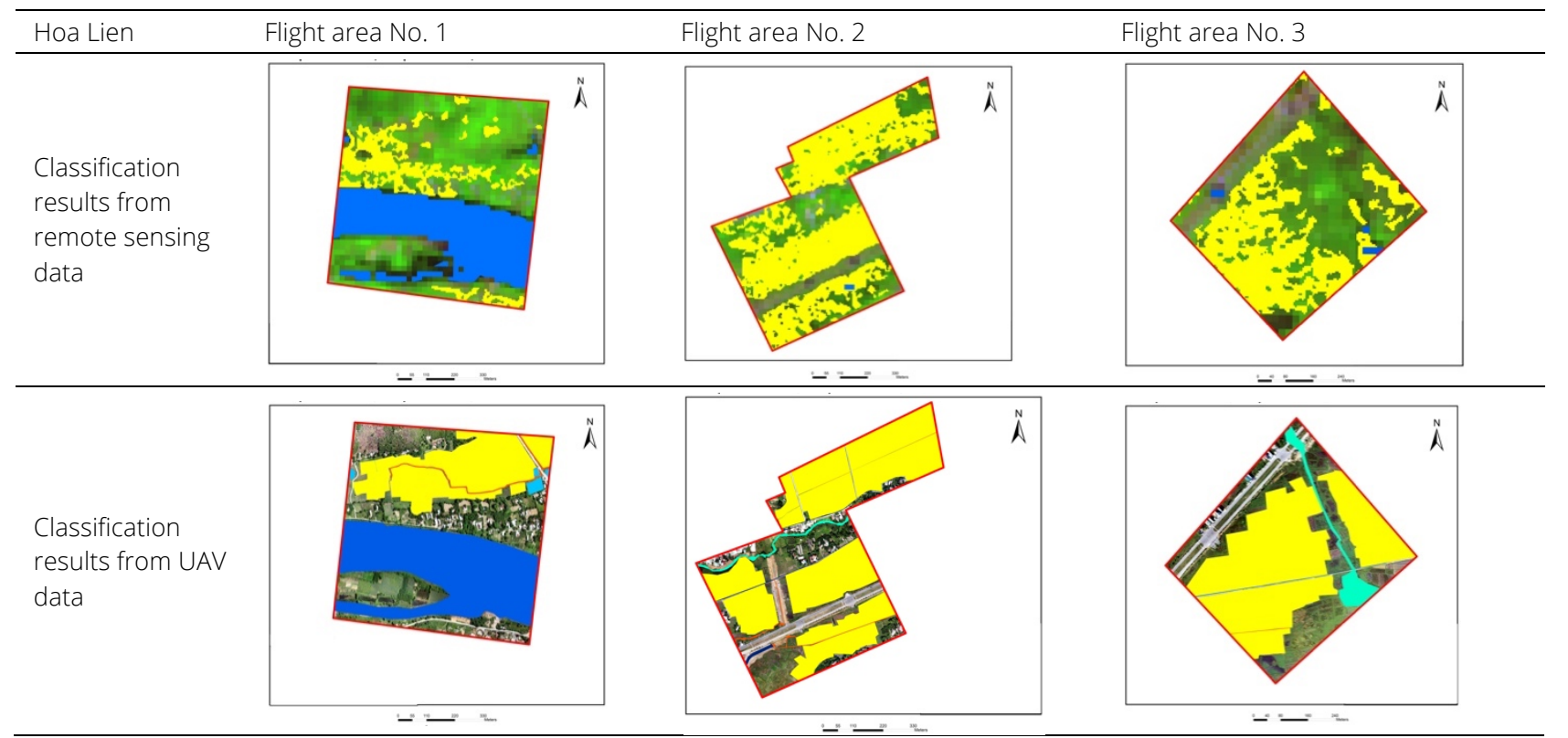

Given these outcomes, the aforementioned objects were mapped for each flight area in order to compare classification results from remote sensing and UAV data (Table 5). 
Classification results from remote sensing data
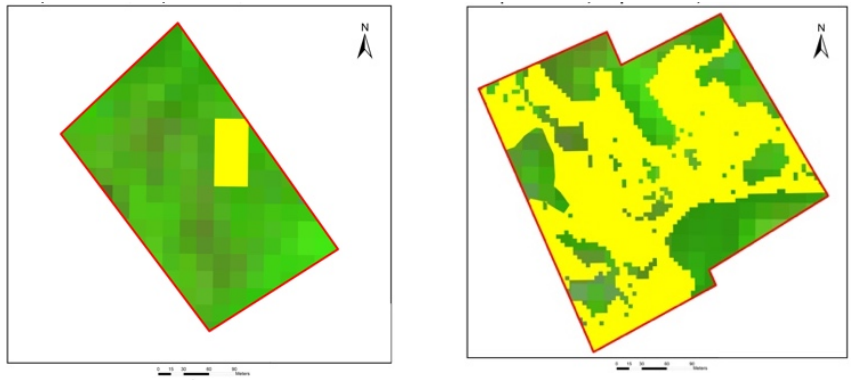

Classification results from UAV data

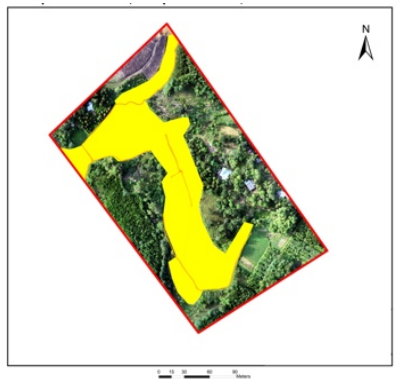

River

Paddy

land
Concrete canal

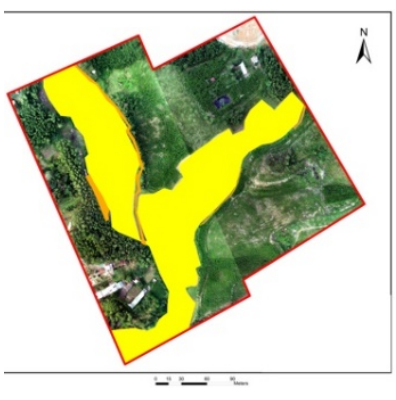

Alluvial canal
Special use water face
Table 5 displays classification results of paddy land and water sources in which classification from UAV data is more precise than remote sensing data. In areas with a concentrated distribution of paddy land, such as the Hoa Lien commune, classification results from remote sensing imagery displayed many advantages; classification from remote sensing data displayed less disparity in comparison with those from UAV data. However, in some areas of the Hoa Ninh commune with fragmented paddy areas due to the influence of topographical conditions, the classification of paddy land was challenging.

It can be seen that there was much variation in the results of rice land objects classification between remote sensing data and UAV data. With the support of high-resolution UAV data, irrigation canal objects defined more accurately in all flight areas. Results showed that there were large areas of paddy land in the Hoa Lien commune and most of the irrigation canals of are concreted. However, in the upper part of the Cu De river, located in the north of the Hoa Lien commune (Flight area No.1), only alluvial canals were classified. In the Hoa Ninh commune, the classified paddy land area is small and the irrigation systems are primarily alluvial canals.

\subsection{Combining UAV and RS data in supporting precision mapping of irrigation system for paddy land}

This research utilized the image classification tool in ArcGIS software to adjust the classification results from remote sensing in the Hoa Vang district. Adjustments were based on the supplementary classification from UAV data including paddy land, water sources and other land types. (Fig. 5).
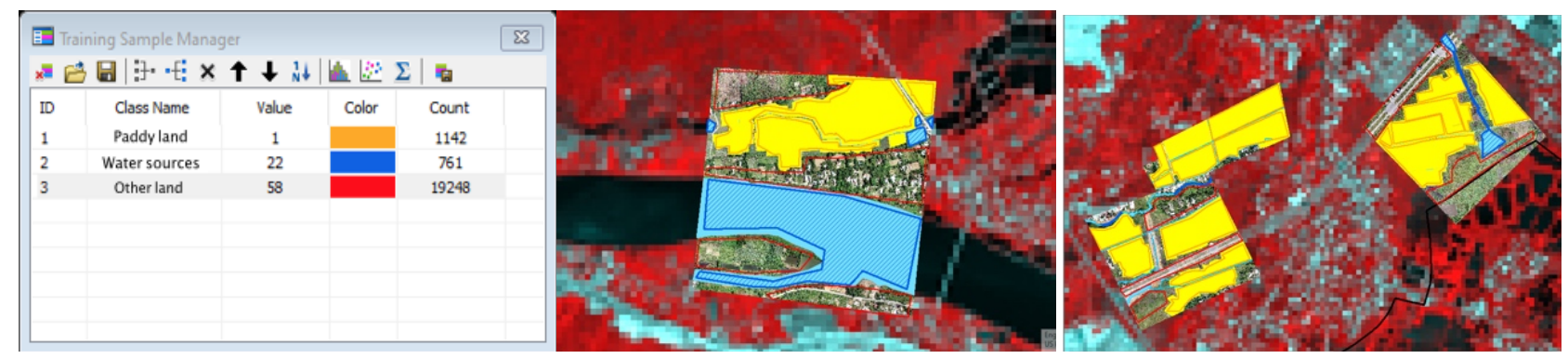

Figure 5. Sampling remote sensing image to adjust classification results based on UAV data

After sampling, remote sensing images were classified according to the interactive supervised classification method. In addition to the objects coinciding with the classification derived from the object-oriented method, sampling classified objects from UAV data supplemented new classification objects; this eliminated misinterpreted 
objects from the previous method. The adjusted maps of paddy land and water sources, from remote sensing data combined with UAV data, in the Hoa Vang district and in two surveyed communes (Hoa Lien and Hoa Ninh) are shown in Fig 6 and Fig 7.

\section{ADJUSTMENT MAP OF PADDY LAND AND WATER SOURCES IN HOA VANG DISTRICT, DA NANG CITY}

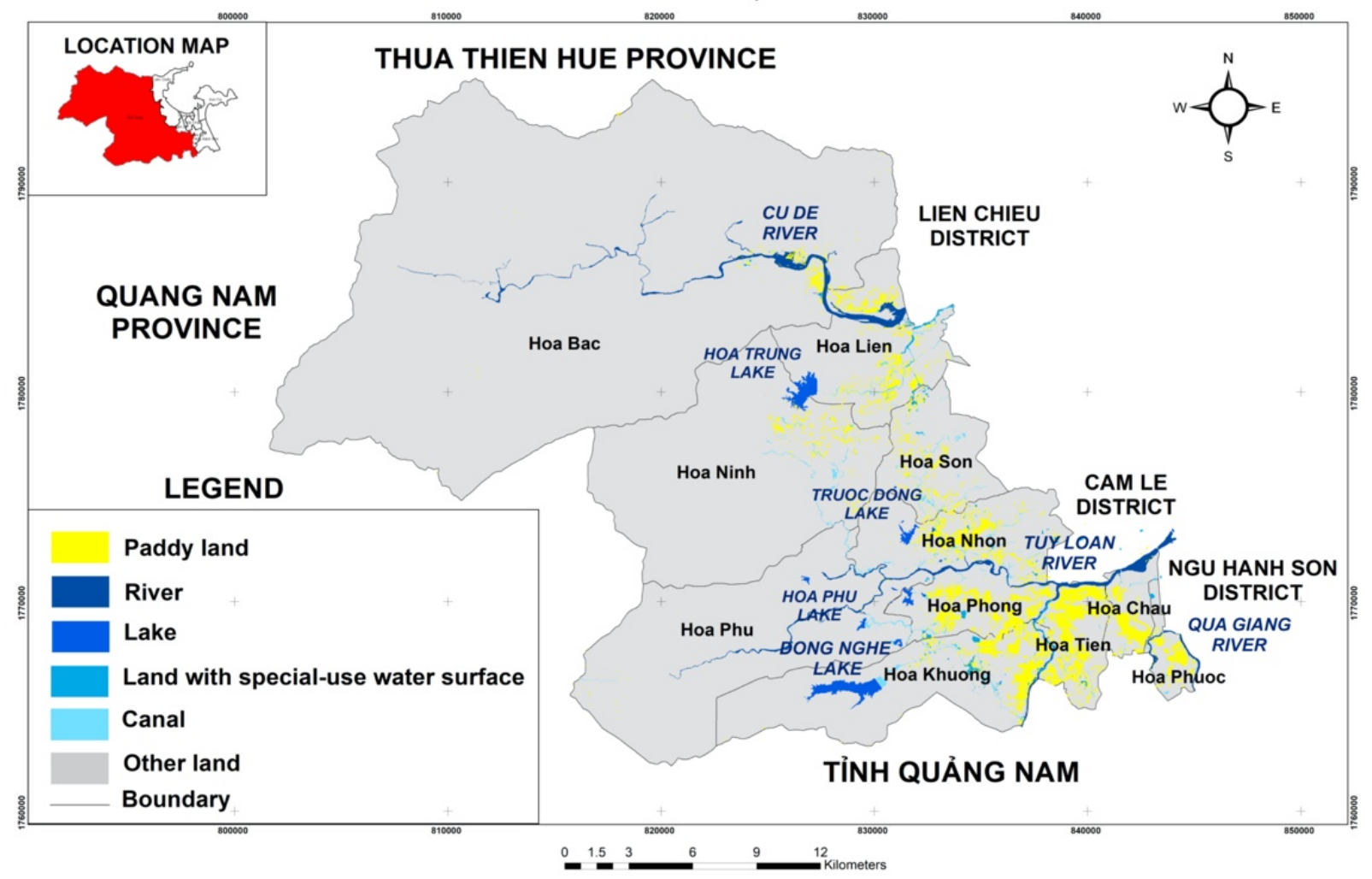

Figure 6. Adjustment map of paddy land and water sources in Hoa Vang district, Da Nang city

ADJUSTMENT MAP OF PADDY LAND AND WATER SOURCES IN HOA LIEN COMMUNE, HOA VANG DISTRICT

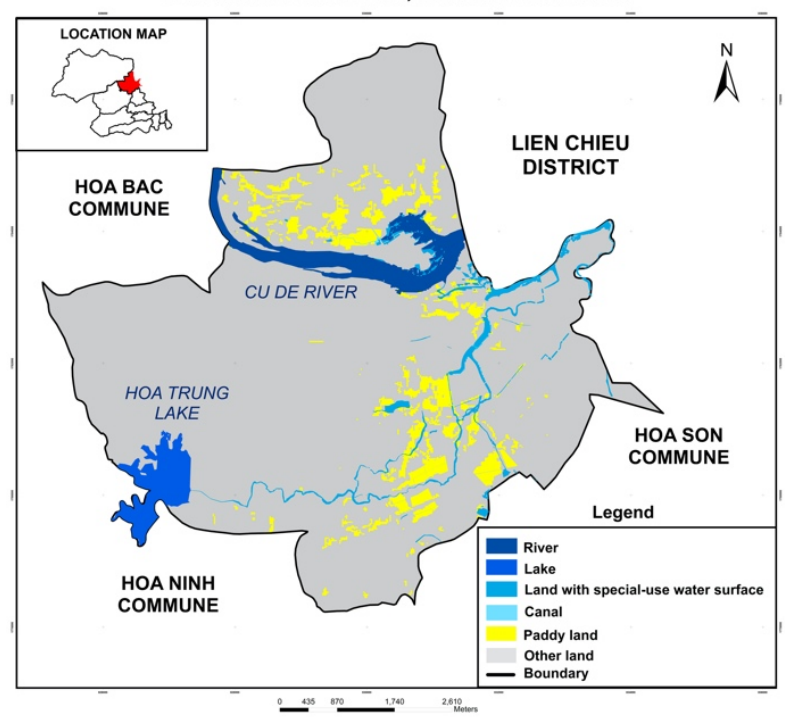

ADJUSTMENT MAP OF PADDY LAND AND WATER SOURCES IN HOA NINH COMMUNE, HOA VANG DISTRICT

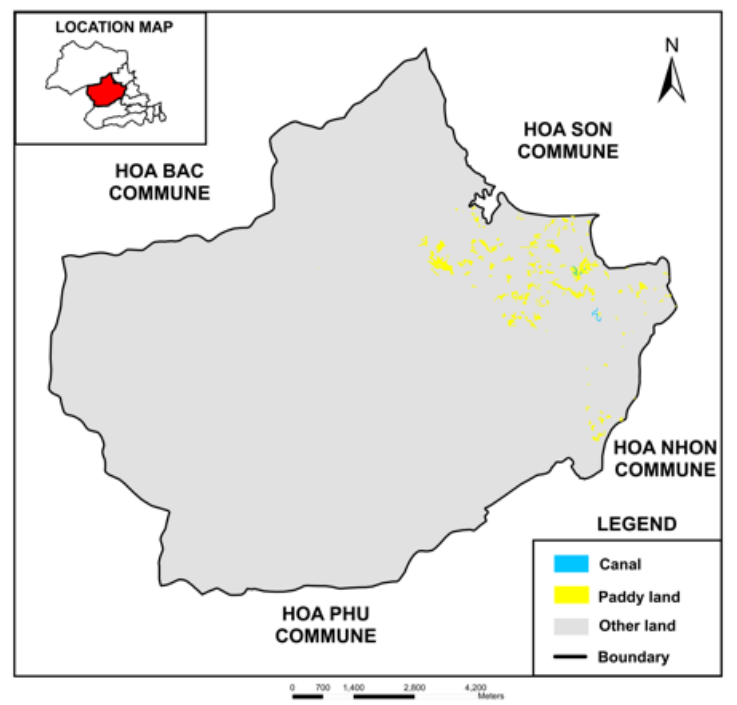

Figure 7. Adjustment map of paddy land and water sources in Hoa Lien and Hoa Ninh commune, Hoa Vang district

It was clearly demonstrated that the paddy land and water source systems (including rivers, lakes, canals and land with special-use water surface) of Hoa Vang district are more detailed by including classification results from UAV data. This demonstrates the effectiveness in improving the detail and accuracy for supplement classification results on remote sensing images. 


\section{Conclusions}

The need for spatial, temporal and spectral resolutions in land cover observation has motivated the development of new-generation satellites and the employment of technologies such as UAVs. This paper presents an integral scheme based on the combination of remote sensing and UAVs for supporting precision mapping of irrigation systems for paddy land in an urban agriculture area. The results of this study demonstrate that the Sentinel $2 \mathrm{~A}$ imagery, interpreted by object-oriented classification method, displays a total accuracy of $91.33 \%$ with a Kappa coefficient of 0.87 to map paddy land and irrigation system for the Hoa Vang district. However, it is difficult to classify paddy land and water from other objects with small areas and a scattered distribution in urban agriculture area such as Hoa Vang district with spatial resolution of $20 \mathrm{~m} \times 20 \mathrm{~m}$. Therefore, we designed five experimental flight zones in two communes (Hoa Lien and Hoa Ninh) with 2,085 images to collect spatial data by UAVs. It can be seen the data from the very high spatial resolution of UAV can identify and clearly distinguish not only the boundaries of paddy land parcel and water sources such as rivers and lakes, but also can distinguish of canals, concrete irrigation system objects. The classification results of orthogonal images of five experimental zones by UAV using object-oriented classification method this paper was correct the interpretation results of the Sentinel 2A image.

\section{References}

[1] Anthony J. Viera và Joanne M. Garrett (2005). Understanding Interobserver Agreement: The Kappa Statistic", Family Medicine 2005, N. 35, pp. 360-363.

[2] Bazzi, H., Baghdadi, N., El Hajj, M., Zribi, M., Minh, D.H.T., Ndikumana, E., Courault, D., Belhouchette, H. (2019). Mapping Paddy Rice Using Sentinel-1 SAR Time Series in Camargue, France. Remote Sens, 11, 8879 .

[3] Catus Aries Rokhmana. (2015). The potential of UAVbased remote sensing for supporting precision agriculture in Indonesia, Procedia Environmental Sciences, 24, $245-253$.

[4] Cohen J. (1960). A coefficient of agrrement for norminal scales, Educ. Psychol. Measurement., 20, 1, pp 37-46.

[5] Demarez, V., Helen, F., Marais-Sicre, C., Baup, F. (2019). In-Season Mapping of Irrigated Crops Using Landsat 8 and Sentinel-1 Time Series. Remote Sens, $11,118$.

[6] Dheeravath, V., Thenkabail, P.S., Chandrakantha, G., Noojipady, P., Reddy, G.P.O., Biradar, C.M., Gumma, M.K., Velpuri, M. (2010). Irrigated areas of India derived using MODIS $500 \mathrm{~m}$ time series for the years 2001-2003. ISPRS J. Photogramm. Remote Sens. 65, 42-59.
[7] Dimosthenis C. Tsouros, \& el. (2019). A review on UAV-based application for precision Agriculture, IOT4 Workshop, MDPI.

[8] Feng, Q., Yang, J., Zhu, D., Liu, J., Guo, H., Bayartungalag, B., Li, B. (2019). Integrating Multitemporal Sentinel-1/2 Data for Coastal Land Cover Classification Using a Multibranch Convolutional Neural Network: A Case of the Yellow River Delta. Remote Sens.11, 1006.

[9] Gumma, M.K., Thenkabail, P.S., Hideto, F., Nelson, A., Dheeravath, V., Busia, D., Rala, A. (2011). Mapping Irrigated Areas of Ghana Using Fusion of $30 \mathrm{~m}$ and 250 m Resolution Remote-Sensing Data. Remote Sens, 3, 816-835.

[10] Gao, Q., Zribi, M., Escorihuela, M., Baghdadi, N., Segui, P. (2018). Irrigation Mapping Using Sentinel-1 Time Series at Field Scale. Remote Sens, 10, 1495

[11] Han, W.T., Shao, G.M., Ma, D.J. (2018). Estimating method of crop coefficient of maize based on UAV multispectral remote sensing. Trans. Chin. Soc. Agric. Mach. 49, 134-143.

[12] Henri Eisenbeiss. (2011). The Potential of Unmanned Aerial Vehicles for Mapping, Photogrammetric Week 11, Eisenbeiss.

[13] Mengmeng Du \& Noboru Noguchi. (2017). Monitoring of Wheat Growth Status and Mapping of Wheat Yield's within Field Spatial Variations Using Color Images Acquired from UAV-camera System, Remote Sensing, 9, 289, doi:10.3390/rs9030289.

[14] Ozdogan, M., Yang, Y., Allez, G., Cervantes, C. (2010). Remote Sensing of Irrigated Agriculture: Opportunities and Challenges. Remote Sens. 2, 2274-23040.

[15] Ren,W.,Wu, D., Qin, L. (2016). Preliminary Study on Data Collecting and Processing of Unmanned Airship Low Altitude Hyperspectral Remote Sensing. Ecol. Environ. Monit. Three Gorges, 1, 52-57.

[16] Ribeiro-Gomes, K., Hernandez-Lopez, D., Ortega, J.F., Ballesteros, R., Poblete, T., Moreno, M.A. (2017). Uncooled Thermal Camera Calibration and Optimization of the Photogrammetry Process for UAV Applications in Agriculture. Sensors, 17, 2173.

[17] Siebert, S., Kummu, M., Porkka, M., Döll, P., Ramankutty, N., Scanlon, B.R. (2015). A global data set of the extent of irrigated land from 1900 to 2005. Hydrol. Earth Syst. Sci., 19, 1521-1545.

[18] Salmon, J.M., Friedl, M.A., Frolking, S., Wisser, D., Douglas, E.M. (2015). Global rain-fed, irrigated, and paddy croplands: A new high-resolution map derived from remote sensing, crop inventories and climate data. Int. J. Appl. Earth Obs. Geoinf, 38, 321-334.

[19] Tilman, D., Clark, M. Food. (2015). Can We Feed the World \& Save the Earth? Agriculture \& the Environment, Daedalus, 144, 8-23. 
[20] Thenkabail, P.S., Biradar, C.M., Noojipady, P., Dheeravath, V., Li, Y., Velpuri, M., Gumma, M., Gangalakunta, O.R.P., Turral, H., Cai, X., \& al. (2009).
Global irrigated area map (GIAM), derived from remote sensing, for the end of the last millennium. Int. J. Remote Sens, 30, 3679-3733. 